TABLE II Components of pre-use anacsthetic machine checklist

Reserve cylinders

High pressure leak

Pipeline connections

Pipeline pressures

Gas flows (flowmeters)

$\mathrm{O}_{2}$ Pressurc failure device and alarm

- During cylinder operation

- During pipeline operation

Machine circuit leak tes!

- Vapourizers on

- Vapourizers off

Vapourizers - confirm off

$\mathrm{O}_{2}$ Flush valve

Scavenging system

Breathing Circuit

Monitors/alarms

d. Operator training and operator vigilance: These are likely the most important factors.

\section{References}

1 Wyant GM. Mechanical Misadventures in Anaesthesia. Lniversity of Toronto Press, Toronto, 1978.

2 Rendell-Baker L. Problems with anesthetic gas machines and their solutions. L. Rendell-Baker. ed, Problems with Anesthetic and Respiratory Therapy Equipment, International Anesthesiology Clinics, Little Brown, Boston, 1982, Vol 20, \#3: $1-82$.

3 Dorsch JA, Dorsch SE. Common Equipment Problems. Annual Refresher Coursc Outlines. American Society of Anesthesiologists Annual Meeting 1980; 202: $1-7$.

4 Dorsch JA, Dorsch SE. Understanding Equipment. Construction, Care and Complications. Williams and Wilkins, Baltirnore, 1975.

5 Cooper JB. Preventable Anaesthetic Mishaps: Causes and Cures. Refresher Course Program. Canadian Anaesthetists' Society Annual Meeting, Quebec City, May, 1982; 40-9

6 Cooper JB, Newbower RS, Long CD, McPeck $B$. Preventable anesthesia mishaps! a study of human factors. Anesthesiology 1978; 49: 399406.

7 Cooper JB. Prevention of Anesthetic Mishaps. Annual Refresher Course Outlines. American Society of Anesthesiologists Annual Meeting 1983; 119: $1-7$.

8 Newbower $R S$, Cooper $J B$, Long $C D$. Failure analysis - the human element. Gravenstein JS, Newbower RS, Ream AK, Smith NT, eds, Essential Noninvasive Monitoring, Grune \& Stratton, New York, 1980; Chap 14: 269-81.

9 Continuous Flow Inhalation Anaesthetic Apparatus (Anaesthetic Machines) for Medical Use. CSA Standard 2168.3-M 1980. Canadian Standards Association, Rexdale, 1980.

10 Craig DB, Longmuir J. Implementation of Canadian Standards Association Z168.3-M 1980. Anaesthetic Gas Machine Standard: The Manitoba Experience. Can Anaesth Soc J 1980; 27: 504-9

11 Cooper JB. Newbower RS, Welch JP, Dedrick $D F$. Preparation for induction. Lebowitz PW, Newberg, LA, Gillette MT, eds, Clinical Anesthesia Procedures of the Massachusetts General Hospital, 2nd ed, Little Brown, Boston, 1982; Chap 2: $10-40$.

\title{
Monitoring anaesthetic practice
}

J.M. Davies mSC MD FrCP(C), Assistant Professor, Department of Anaesthesia, Foothills Hospital at the University of Calgary, Calgary, Alberta.

Of the many methods of studying morbidity/ mortality in anaesthesia, and thus monitoring anaesthetic practice, six will be described.

Anecdotal tales are usually reports of anaesthetic rarities, occurring at a rate of " $l /$ ?", and often bearing little relevance to day-to-day practice, e.g., "blue jumpers and pink trousers." However, these reports may lead to more detailed studies once a problem has been identified.

In-hospital audit involves review of the written anaesthetic record, the making and keeping of which is mandatory in most parts of the world. Review is facilitated by computerisation, allowing quantification of the rates of death and other major complications although, even in the best regulated institutions, records may be incomplete or missing. Also, the low incidence of untoward events ${ }^{2}$ re- 
quires that a large number of procedures be canied out to allow accurate calculation of true risk of morbidity/mortality. Furthermore, anaesthetic related complications may occur in the first postoperative week, ${ }^{3}$ and these are not usually noted on the anaesthetic record, nor are they always recognised. But, for the clinical anaesthetist, in-hospital audit provides the best method of self and peer monitoring.

Reports to medical protective societies are made in two situations: (1) involvement in an incident which may have potential for litigation and (2) involvement in a lawsuit. Every year the societies publish a report of "interesting cases;" in 1979, the Medical Defence Union of the United Kingdom reviewed ${ }^{4}$ anaesthetic accidents during 1970-77. Of the 71 cases of cerebral damage, faulty technique was responsible for 60.6 per cent and "anaesthesiologist failure" for 4.2 per cent. This latter category was defined as "absence of the anaesthesiologist from the operating room when something went wrong with the patient," an indefensible situation.

Retrospective studies have been the major method of investigating problems with anaesthesia. However, the disadvantages are multiple: failure to record significant events at the time of occurrence, failure to store records leading to loss, a changing pattern of clinical practice, and in the case of multicentre studies which these often are, a lack of uniformity of assigned values. An example of the latter is the definition of death associated with anaesthesia. Harrison's 1978 study $^{5}$ defined death as "occurring during or within 24 hours of anaesthesia" and showed a frequency of $1 / 4537$ anaesthetics whereas the Association of Anaesthetists of Great Britain and Ireland in 1982 reported $^{2}$ a death rate of $1 / 10,000$ for a six-day postanaesthetic period.

Specific anaesthetic-related problenis usually surface in the medical press, first in the correspondence column or as a leading article, and then, as a report of a study. An example is the National Halothane Study, which probed the problem of halothane-associated hepatitis with a retrospective study of some one million patients in 34 institutions. Only seven patients were found where the consensus was that halothane might have been responsible, an apparent incidence of $1 / 10,000$.

Prospective studies are the best way of investigating medical problems. However, there must be a working hypothesis and, when looking for rarities, large numbers of patients need to be studied, often requiring the expenditure of large numbers of dollars. An example of this is a multicentre study of four general anaesthetics in 25,000 patients over two years at a cost of US $\$ 1,000,000$, currently being carricd out in North America.

In conclusion, there are many methods of monitoring anaesthetic practice, from peer review to intermational enquiry. The specialty of anaesthesia has recognised that problems exist and is making attempts to quantify these and address possible solutions. ${ }^{3}$

\section{References}

1 Hughes $D G$, Longam $M$, Ryan $D W$. Blue jumpers and pink trousers. Anesth Analg 1981; 60: 453-4.

2 Lum JN, Mushin WW. Mortality associated with anaesthesia. Nuffield Provincial Hospital Trust, Londan, 1982.

3 Lunn JN. Deaths associated with anaesthesia. Anaesthesia 1979; 34: 229-30.

4 Utting IE, Gray TC, Shelley FC. Human misadventure and anaesthesia. Can Anaesth Soc J 1979; 26: $472-8$.

5 Harrison FF. Death attributable to anaesthesia. A 10-year survey (1967-1976). Br J Anaesth 1978; 50: 1041-6.

\section{Postoperative assessment of the effects of anaesthetic agents}

J.R. Maltby MA MB вCHIR FRCP(c), Clinical Associate Professor, Department of Anaesthesia, Foothills Hospital at the University of Calgary, Calgary, Alberta.

In North America each year approximately 8.5 per cent of the population or 21 million patients receive general anaesthesia for surgery and 235,000 of 